DOI : 10.14746/pp.2014.19.4.14

\title{
Małgorzata MIZERSKA-WROTKOWSKA
}

Uniwersytet Warszawski

\section{Działalność międzynarodowa Drugiej Republiki Hiszpańskiej}

Streszczenie: Celem artykułu jest ukazanie aktywności międzynarodowej Hiszpanii w latach 1931-1936, czyli w okresie Drugiej Republiki. W artykule podjęto problemy zmierzające do odpowiedzi na następujące pytania badawcze: (1) Na czym polegała reorganizacja hiszpańskich struktur dyplomatycznych po przemianach ustrojowych roku 1931?; (2) Kto był odpowiedzialny za kształtowanie polityki zagranicznej Hiszpanii w okresie Drugiej Republiki?; (3) Jak kształtowały się relacje z najważniejszymi aktorami sceny międzynarodowej?; (4) W czym przejawiała się hiszpańska działalność na forum Ligi Narodów? Przy pisaniu artykułu wykorzystano metodę analizy i krytyki źródeł oraz analizę porównawczą dostępnych, głównie hiszpańskojęzycznych, publikacji.

Autorka dochodzi do wniosku, że hiszpańska polityka zagraniczna w okresie Drugiej Republiki nie była imponująca, ale stanowiła wypadkową możliwości państwa. Była też dostosowana do trudnych okoliczności międzynarodowych oraz wewnętrznych wyznaczników ideologicznych. Polityka ta uległa transformacji: od kultywowania wielkich ideałów pacyfistycznych do pragmatycznej neutralności i realizmu.

Słowa kluczowe: Druga Republika Hiszpańska, pacyfizm, relacje bilateralne, Liga Narodów

D ruga Republika została ustanowiona w Hiszpanii 14 kwietnia 1931 r. ${ }^{1}$, kiedy w stosunkach międzynarodowych w Europie wyczuwalne już były pewne napięcia. Był to okres rozwoju nazizmu, faszyzmu, konsolidacji Związku Radzieckiego. Odczuwalne były też skutki kryzysu ekonomicznego z 1929 r. (Egido León, 2000, s. 189-190; Pereira, Neila, 1989, s. 112-113).

\section{Organizacja dyplomacji hiszpańskiej w nowym ustroju}

Zaraz po ustanowieniu republiki wielu dyplomatów, którzy byli desygnowani na swe stanowiska w okresie dyktatury generała Miguela Primo de Rivery złożyło dymisję. Skala zjawiska była tak duża, że Kortezy przyjęły dekret o wcześniejszej emeryturze dla dyplomatów, którzy rezygnowali z pełnionych funkcji, gdyż nie chcieli wyrzec się swoich sympatii do poprzedniego ustroju. Zaistniała więc potrzeba uzupełnienia wakatów ludźmi, którzy oddani byli władzy republikańskiej. Wiele stanowisk ambasadorskich objęli intelektualiści: pisarz i dziennikarz Ramón Pérez de Ayala został ambasadorem w Wielkiej Brytanii, filozof i historyk Américo Castro - w Niemczech, a pisarz i historyk Salvador de Madariaga - najpierw w USA, a potem we Francji. W praktyce wysokie

\footnotetext{
${ }^{1} \mathrm{Na}$ temat okoliczności ustanowienia w Hiszpanii republiki oraz przemian wewnętrznych z tym związanych zob. M. Tuñón de Lara (1997, s. 547-568).
} 
stanowiska obejmowały często osoby lojalne wobec reżimu, ale bez odpowiedniego przygotowania i doświadczenia w służbie zagranicznej. Zdarzali się jednak kompetentni politycy, jak np. ministrowie spraw zagranicznych: Luis de Zulueta, Fernando de los Ríos, Augusto Barcia oraz ambasadorowie: wspomniani Ramón Pérez de Ayala, Salvador de Madariaga oraz Julio Álvarez del Vayo.

Niższe stanowiska zarówno w placówkach zagranicznych, jak w MSZ zajmowali nadal zwolennicy ustroju monarchicznego. Utrudniało to prowadzenie spójnej polityki zagranicznej. Dużym problemem w tej materii były też ciagłe zmiany na szczeblu rządowym (Neila Hernández, 2003, s. 467-468). W okresie republiki aż jedenaście razy doszło do zmiany ministra odpowiedzialnego za sprawy zagraniczne. Łącznie do 19 VII 1936 r. funkcję tę pełniło dziesięciu polityków (Alejando Lerroux García ministrem spraw zagranicznych był dwukrotnie: 14 IV-16 XII 1931 oraz 25 IX-29 X 1935). Niekorzystnie na politykę zagraniczną wpływały też zawirowania w polityce wewnętrznej: nieudany zamach stanu z 1932 r. zorganizowany przez generała José Sanjurjo (tzw. „La Sanjurjada"), wydarzenia z Casas Viejas ${ }^{2}$, anarchistyczne powstania, zawirowania w armii i Kościele (Pereira, Neila, 1989, s. 103-104; Egido León, 2000, s. 191-192, 217; Pereira, 1983, s. 161).

\section{Hiszpański pacyfizm i wizjonerzy polityki zagranicznej okresu Drugiej Republiki}

Wiele cech polityki zagranicznej Hiszpanii z okresu Drugiej Republiki odzwierciedla konstytucja z $1931 \mathrm{r}$. Cechy te to pacyfizm i przywiązanie do wartości stojących u podstaw Ligi Narodów. W artykule 6 konstytucji Hiszpania wyrzekła się wojny, jako sposobu rozstrzygania sporów, w artykule 7 - zobowiązała się do przestrzegania uniwersalnych norm prawa międzynarodowego, natomiast w 65 - uznała wyższość tych norm nad przepisami prawa wewnętrznego. W artykule 77 Hiszpania zgodziła się by ewentualne wypowiedzenie wojny miało miejsce na warunkach określonych w Pakcie Ligi Narodów, po wyczerpaniu środków koncyliacyjnych i arbitrażowych przewidzianych w wiążących ją traktatach. Natomiast artykuł 78 przewidywał, że ewentualne wystąpienie Hiszpanii z Ligi Narodów może nastąpić jedynie na podstawie specjalnej uchwały przyjętej przez parlament. Konstytucja ta uwzględniająca zapisy Paktu Ligi Narodów oraz Paktu Brianda-Kelloga wpisała się w nurt międzynarodowego pacyfizmu prawnego lat 30. XX w. (Moradiellos, 2003, s. 69-70; Neila Hernández, 2003, s. 464-465).

Ustawa zasadnicza z $1931 \mathrm{r}$. zrobiła też ukłon w stronę Portugalczyków i państw Ameryki Łacińskiej, gdyż ułatwiła ich obywatelom nabywanie podwójnego obywatelstwa (art. 24). Dała też szansę nabycia obywatelstwa osobom o hiszpańskich korzeniach rezydującym za granicą (art. 23). Zapis ten dotyczył zwłaszcza wygnanych z Hiszpanii jeszcze za czasów królów katolickich Żydów sefardyjskich (Pereira, Neila, 1989, s. 112; Egido León, 2000, s. 194-195).

\footnotetext{
${ }^{2}$ Krwawe starcia z anarchistami w styczniu 1933 r. w miejscowości Casas Viejas, w wyniku których śmierć poniosło ponad 20 osób. Incydent ten doprowadził do kryzysu politycznego, a w konsekwencji do upadku socjalistycznego rządu Manuela Azañi.
} 
Za twórców hiszpańskiej polityki zagranicznej okresu republikańskiego należy uznać Salvadora de Madariagę oraz Manuela Azañę. Obaj politycy mieli jednak nieco inne wizje działalności zewnętrznej państwa. De Madariaga - ambasador w USA i Francji, długoletni przedstawiciel Hiszpanii przy Lidze Narodów - kładł nacisk na wzmocnienie szczerej i efektywnej współpracy międzynarodowej (zob. Madariaga Álvarez-Prida, 2009, s. 85-95). Nawoływał do współpracy z państwami neutralnymi i kultywowania ścisłego sojuszu z Wielką Brytanią i Francją. Sugerował też przyjaźń z Portugalią i dobre relacje z obu Amerykami. Manuel Azaña był natomiast zwolennikiem odpowiedzialnej, pozytywnej neutralności (neutralidad responsable, neutralidad positiva), nie oznaczającej jednak wyizolowania oraz aktywnego pacyfizmu (pacifismo activo), nie wynikającego jednak z niemocy czy bezbronności (Neila Hernández, 2003, s. 455; Egido León, 2000, s. 195-196). De Madariaga skupiał się więc na realizowaniu interesów narodowych przez pryzmat współpracy międzynarodowej, a realista Azaña - na bezpośredniej ochronie hiszpańskiej racji stanu (Neila Hernández, 2003, s. 458-460).

\section{Relacje z Francją i Wielką Brytanią}

Jednym z tradycyjnych partnerów Hiszpanii od zawsze była Francja. W relacjach z tym państwem w okresie Drugiej Republiki były pewne problemy. Po pierwsze, Paryż przyjął hiszpańskich emigrantów politycznych z samym królem Alfonsem XIII na czele. Hiszpania i Francja różniły się również w sprawie delimitacji terytoriów w Maroku oraz statusu Tangeru. Ponadto, Francja utrzymywała swoje ograniczenia ilościowe na hiszpańskie towary. Szanse na polepszenie relacji pojawiły się jednak już w 1932 r. wraz z utworzeniem we Francji socjalistycznego rządu Édouarda Herriota. Pod koniec tego samego roku doszło do legendarnej wizyty nowego premiera w Madrycie. Pojawiły się nawet spekulacje, że przy tej okazji doszło do zawarcia tajnego paktu, w którym Hiszpania zgodziła się na przemarsz francuskich sił z Afryki w razie ewentualnego konfliktu zbrojnego. Dziś już wiadomo na pewno, że takiego układu nie podpisano. Oba państwa zbliżyły natomiast swe stanowiska w sprawie rozbrojenia - jednego z głównych wątków w ówczesnej dyskusji na forum Ligi Narodów. Hiszpania i Francja podpisały też umowy w sprawie wzajemnej ochrony praw pracowniczych. Największe kontrowersje związane z tą wizytą wzbudził chłodny dystans hiszpańskiego premiera - Manuela Azañi - który nie zgodził się nawet na rozmowę z Herriotem w cztery oczy. Wierny zasadzie neutralności nie chciał stwarzać wrażenia, że Hiszpania ma szczególne powiązania z jakimkolwiek państwem.

Mimo to, wizyta Herriota w Hiszpanii przyniosła wymierne efekty zwłaszcza dzięki osobistemu zaangażowaniu nowych ministrów spraw zagranicznych: Josepha Paula Boncoura i Fernanda de los Ríos. Pod koniec 1932 r. nastapił wzrost zainteresowania Hiszpanią francuskich mediów. Zwiększyła się wymiana kulturalna. Francja zaoferowała też pomoc w nawiązaniu stosunków dyplomatycznych między Hiszpanią a ZSRR. Po zmianie rządu w Hiszpanii i lekkim ochłodzeniu relacji zaktualizowano porozumienie w sprawie Tangeru (Hiszpania uzyskała jedynie drobne korzyści) oraz zawarto umowy o handlu i żegludze. Zbliżenie hiszpańsko-francuskie w okresie rządów Drugiej Republiki należy uznać jednak za iluzoryczne, o czym świadczy brak poparcia przez Francję sił 
republikańskich podczas wojny domowej (Egido León, 2000, s. 199-201, 205; Pereira, 1983, s. 162).

Wielka Brytania przyjęła powstanie Drugiej Republiki w Hiszpanii z pewną rezerwą. Oba państwa reprezentowały inne podejścia do polityki w regionie Morza Śródziemnego. Różniła je też kwestia Gibraltaru oraz rozbieżne interesy handlowe. Jednak dzięki działalności ambasadorów: George'a Grahame'a i Ramóna Pérez de Ayala relacje się ociepliły (Pereira, Neila, 1989, s. 106; Egido León, 2000, s. 206; Pereira, 1983, s. $162-163)$.

\section{Relacje z Niemcami i Wlochami}

Stosunki Hiszpanii z Niemcami nie były zbyt intensywne. Niemcy mogły obawiać się ewentualnego porozumienia Hiszpanii z Francją. Jednak po wielokrotnej demonstracji hiszpańskiej neutralności obawy te ucichły. Hiszpania nie znajdowała się w orbicie bezpośrednich zainteresowań Hitlera. Po dojściu do władzy koalicji radykalno-cedystowskiej relacje z Niemcami jednak się zacieśniły: handlowano bronią, wielu hiszpańskich polityków odbywało podróże do Niemiec ${ }^{3}$, rząd hiszpański zaproponował nawet współpracę hiszpańskiej policji z Gestapo (Pereira, 1983, s. 163). Wtedy też zostały ustanowione kanały, którymi Niemcy dostarczały pomoc nacjonalistom podczas wojny domowej (Egido León, 2000, s. 209-210; Pereira, Neila, 1989, s. 108-109).

Relacje z Włochami były bardziej skomplikowane. Utrudniały je nie tylko włoskie obawy o istnienie tajnego hiszpańsko-francuskiego układu wojskowego, ale również inwazja Włoch na Abisynię oraz pertraktacje z Włochami hiszpańskich dysydentów generała Sanjurjo, którzy w zamian za dostawy broni byli gotowi po ewentualnym zwycięstwie na pewne ustępstwa w Afryce. W porozumieniu zawartym z hiszpańskimi konspiratorami w 1934 r. Mussolini ${ }^{4}$ zgodził się wesprzeć ich w obaleniu republiki w zamian za zawarcie układu handlowego i umowy przyjaźni, neutralność, utrzymanie status quo na Morzu Śródziemnym oraz wycofanie się z domniemanego (o którym była wcześniej mowa) układu wojskowego z Francją (Egido León, 2000, s. 208-209).

\section{Relacje z państwami Ameryki Lacińskiej i Marokiem}

Podstawę dla dobrych relacji z Ameryką Łacińską dała konstytucja z 1931 r., a zwłaszcza jej artykuły: 24 - traktujący o podwójnym obywatelstwie, o którym była już mowa oraz 50 - o współpracy kulturalnej. W okresie republiki wzmocniono obecność

\footnotetext{
${ }^{3}$ Takie podróże odbyli m.in.: José María Gil Robles - lider CEDA (Hiszpańskiej Konfederacji Prawicy Autonomicznej), Ángel Herrera - dyrektor powiązanego z CEDA dziennika „El Debate” oraz José Antonio Primo de Rivera (syn Miguela), który zdobył w Niemczech fundusze na założoną przez siebie partię Falangę.

${ }^{4}$ Należy pamiętać, że podczas swej dyktatury ścisłe kontakty z Mussolinim utrzymywał Miguel Primo de Rivera. Włochy wsparły też finansowo działalność Falangi - partii założonej przez jego syna (Pereira, Neila, 1989, s. 107).
} 
dyplomatyczną w regionie, podnosząc do rangi ambasad niektóre poselstwa oraz tworząc nowe przedstawicielstwa. Hiszpania nadal pragnęła przewodzić grupie państw hispanoamerykańskich na forum Ligi Narodów. Dlatego też zaangażowała się w roli mediatora w spór między Kolumbią i Peru o miasto Leticia (ostatecznie przyznano je Kolumbii) oraz między Boliwią i Paragwajem o region Chaco (tu mediacja okazała się nieskuteczna). Spośród państw latynoamerykańskich najściślejsze relacje nawiązano z Meksykiem. To właśnie to państwo wsparło republikanów podczas wojny domowej, stało się domem dla emigrantów politycznych oraz siedzibą lewicowego rządu na uchodźctwie (Egido León, 2000, s. 211-212; zob. też: Neila Hernández, 2003, s. 462-463).

W Maroku rząd republikański miał dwa cele: ograniczyć liczbę stacjonujących tam żołnierzy oraz obniżyć koszty zarządzania prowincją. Postulaty te nie podobały się części wojskowych, którzy pobyt w Afryce traktowali jako dobrą okazję do awansu. Wojsko pozostałe w Maroku zradykalizowało swoje poglądy. Rozpoczął się proces przygotowywania gruntu pod bunt generałów, który doprowadził do wybuchu wojny domowej. Pojawiające się symptomy nacjonalizmu marokańskiego spotkały się natomiast $\mathrm{z}$ brakiem zainteresowania i niezrozumieniem strony hiszpańskiej. Ponadto, reprezentujący władzę cywilną Wysocy Komisarze zakazali rdzennej ludności działalności politycznej. Ograniczenie więc kontroli wojskowej w Maroku szło w parze ze zwiększeniem presji na ludność cywilną.

Jednocześnie, w 1934 r. Hiszpania zajęła region Ifni - enklawę w zachodniej Afryce, naprzeciw Wysp Kanaryjskich przyznaną jej na mocy układu z 1884 r., którą jednak do tego czasu zajmowali Francuzi. W sprawie Tangeru Hiszpania liczyła na zwiększenie swych wpływów, korzystając z faktu, że w maju 1936 r. dotychczasowy układ miał wygasnąć. Jednak z uwagi na opóźnianie negocjacji przez Francję i Wielką Brytanię oraz zaangażowanie potencjalnego sojusznika - Włoch - w Etiopii udało się Hiszpanii osiagnąć, jak już wcześniej wspomniano, jedynie minimalne korzyści w sprawach administracyjnych i policyjnych. Niewiele wiadomo o działalności rządu republikańskiego w Gwinei. Pewne jest jedynie to, że w 1935 r. założono tam kolonię karną i podzielono ten obszar na dwa dystrykty: Gwineę kontynentalną i Fernando Poo (dzisiejsza wyspa Bioko) (Egido León, 2000, s. 212- 214).

\section{Relacje z Portugalią}

Relacje Hiszpanii z Portugalią charakteryzowały się w okresie Drugiej Republiki niestabilnością. Za rządów lewicy Hiszpania wspierała portugalską opozycję. Manuel Azaña uczestniczył nawet osobiście w negocjowaniu pożyczki dla portugalskich dysydentów na zakup broni. Po dojściu do władzy sił prawicowych tego typu wsparcie się skończyło. Relacje się ociepliły: Salazar zaproponował zawarcie traktatu o przyjaźni, doszło do kilku wizyt na wysokim szczeblu, wreszcie osądzono odpowiedzialnych za dostawy broni, która miała służyć do zamachu przeciwko portugalskiemu dyktatorowi. Po zwycięstwie w Hiszpanii Frontu Ludowego relacje się ochłodziły. Portugalia stała się centrum operacyjnym hiszpańskich polityków przygotowujących powstanie zbrojne. Nie było wątpliwości, po której stronie opowie się zachodni sąsiad Hiszpanii w zbliżającej się wojnie domowej (Egido León, 2000, s. 214-216; zob. też: Pereira, Neila, 1989, s. 107-108; Neila Hernández, 2003, s. 462). 


\section{Relacje ze Związkiem Sowieckim, Stanami Zjednoczonymi i Watykanem}

Relacje Hiszpanii ze Związkiem Sowieckim nie były tak ścisłe jak mogłoby się pozornie wydawać. Ustrój sowiecki Hiszpania uznała w 1933 r. (po przyjęciu rok wcześniej ZSRR do Ligi Narodów), a do wymiany ambasadorów doszło dopiero w 1936 r. Aż tak duże opóźnienie wynikało z faktu, że przed objęciem funkcji ambasadora zmarł desygnowany na to stanowisko Anatolij Łunaczarski. Siły prawicowe natomiast, które doszły do władzy w 1933 r. podeszły z większą rezerwą do kontaktów z ZSRS. Nie przeszkodziło to jednak by w okresie republiki wielu hiszpańskich polityków i ludzi kultury z Hiszpanii odwiedzało ZSRS. Inicjatorem tych podróży była specjalnie w tym celu powołana organizacja Intourist (Pereira, Neila, 1989, s. 109; Egido León, 2000, s. 216).

Na relacjach Hiszpanii ze Stanami Zjednoczonymi w okresie republiki ciążył duch wydarzeń z 1898 r. Jeden z poważniejszych kryzysów w tych relacjach wiązał się z interpelacją parlamentarną w Kortezach, w której zaproponowano anulowanie umowy między Hiszpanią a Compañía Telefónica należącej do amerykańskiej spółki ITT. Dopiero w wyniku interwencji amerykańskiego ambasadora rozwiązano problem na korzyść USA (Egido León, 2000, s. 217). Oba państwa konkurowały też o wpływy w Ameryce Łacińskiej (Pereira, Neila, 1989, s. 110).

Kontakty z Watykanem były natomiast bardzo napięte, gdyż Hiszpania za czasów Drugiej Republiki była państwem laickim. Władze chciały skończyć z przywilejami kościelnymi, przeprowadzić reformę szkolnictwa oraz zrestrukturyzować własność, a potem rozwiązać Towarzystwo Jezusowe (Compañia de Jesús). To wszystko nie podobało się Kościołowi i doprowadziło do otwartego konfliktu z władzami (Egido León, 2000, s. 217). Ukonstytuowały się jednak dwa stronnictwa w Kościele. Pierwsze objęło grupę zwolenników bezpośredniego starcia z laickimi władzami (m.in. kardynał Pedro Segura - zmuszony do rezygnacji z zajmowanej funkcji i wydalony z kraju oraz kardynał Isidro Gomá), drugie - grupę podążającą za wskazówkami watykańskiego sekretarza stanu Eugenia Pacellego - przyszłego papieża Piusa XII. Sugerował on nie polemizować z władzami, ale nie rezygnować z walki o religię, porządek i własność (Pereira, 1983, s. 164-165).

Zaraz po nastaniu republiki miał miejsce tzw. tragiczny tydzień w Kościele (la semana trágica de la Iglesia). W dniach 8-14 października 1931 r. doszło do ostrych starć w parlamencie przy okazji debaty nad projektem nowej konstytucji i proponowanego w nim kształtu relacji państwo-Kościół (zob. Arbeloa, 2006). Wreszcie ustawa z dnia 2 czerwca 1933 r. uznająca Kościół za „departament administracyjny państwa” (departamento administrativo del Estado) zmusiła papieża Piusa XI do ostrego sprzeciwu wyrażonego w Encyklice „Dilectissima nobis Hispania” (Preira, 1983, s. 165).

${ }^{5}$ W 1898 r., w wyniku przegranej wojny ze Stanami Zjednoczonymi, Hiszpania straciła resztę swoich posiadłości kolonialnych (Kubę, Portoryko, Filipiny, Guam). W 1899 r. sprzedała Niemcom również Karoliny z Palau i Mariany Północne. Wydarzenia te w historii Hiszpanii są nazywane Katastrofą roku 1898 (desastre de 98). 


\section{Działalność Hiszpanii na forum Ligi Narodów}

W okresie Drugiej Republiki Hiszpania aktywnie angażowała się na forum Ligi Narodów. Organizacja ta dała państwom o małym i średnim znaczeniu nowe instrumenty wpływania na stosunki międzynarodowe (Neila Hernández, 2003, s. 457). Hiszpania korzystała z tych możliwości: broniła wspólnych wartości po japońskiej inwazji na chińską Mandżurię ${ }^{6}$, zgłaszała inicjatywy rozbrojeniowe, działała w grupie państw neutralnych (tzw. Grupie Ośmiu). W porozumieniu tym oprócz Hiszpanii uczestniczyły Szwajcaria, Norwegia, Szwecja, Dania, Holandia oraz - do 1936 r. - również Belgia i Czechosłowacja. Po wycofaniu się tych dwóch ostatnich państw powstała tzw. Grupa Sześciu (inaczej Grupa Neutralnych) - stowarzyszenie państw, które były neutralne podczas I wojny światowej i chciały zachować ten status na wypadek ewentualnego konfliktu w przyszłości.

Mimo hiszpańskich wysiłków nie udało się uniknąć fiaska konferencji rozbrojeniowej, która rozpoczęła się w 1932 r. (Moradiellos, 2003, s. 71; Pereira, Neila, 1989, s. 111). Nie powiodła się również realizacja idei Paktu Śródziemnomorskiego (nazywanego również Śródziemnomorskim Locarno) - regionalnego porozumienia w ramach systemu bezpieczeństwa zbiorowego (Neila Hernández, 2003, s. 461). Hiszpania zaangażowała się jeszcze w kryzys związany z włoską inwazją na Abisynię w 1935 r. zdecydowanie domagając się złagodzenia sankcji ekonomicznych ustanowionych wobec Włoch przez Ligę Narodów (Moradiellos, 2003, s. 72).

\section{Konkluzje}

Wśród hiszpańskich badaczy analizujących okres Drugiej Republiki są tacy, którzy sugerują, że Hiszpania w tym okresie była pozbawiona polityki zagranicznej (por. Jover Zamora, 1963, s. 751-794; Tamames, 1976). Powyżej przywołane fakty wydają się jednak przeczyć tej tezie. Należy zgodzić się ze stwierdzeniem, że hiszpańska polityka zagraniczna w tym okresie nie była imponująca, ale stanowiła wypadkową możliwości państwa. Była też dostosowana do trudnych okoliczności międzynarodowych oraz wewnętrznych wyznaczników ideologicznych. Polityka zagraniczna Hiszpanii w okresie Drugiej Republiki uległa transformacji: od kultywowania wielkich ideałów pacyfistycznych do pragmatycznej neutralności i realizmu (Moradiellos, 2003, s. 69) ${ }^{7}$.

Wojna domowa, która wybuchła w $1936 \mathrm{r}$. była spowodowana konfliktem wewnętrznym. Nie była inspirowana z zewnątrz, jak głosiły często propagandy obu stron. Trudno uwierzyć zarówno w komunistyczny spisek zainicjowany przez ZSRS (teza głoszona przez uczestników prawicowego buntu, który doprowadził do wojny), jak i we włosko-niemiecką zmowę, która przesądziła o zamachu stanu (teza republikanów). Pewne

\footnotetext{
${ }^{6}$ Zaangażowanie w tę sprawę hiszpańskiego delegata de Madariagi było tak duże, że otrzymał on przydomek „Don Kiszota Manżurii”. Jednak ani Francja ani Wielka Brytania ani USA nie miały zamiaru włączać się w tak odległy konflikt przeciwko Japonii na rzecz osłabionych i niestabilnych Chin (Moradiellos, 2003, s. 70).

${ }^{7} \mathrm{Na}$ temat polityki zagranicznej Hiszpanii w okresie Drugiej Republiki patrz też: Olivié, 1999, s. 264-291; Palomares Lerma, 1994, s. 62-70; Powell, 1995, s. 30-32.
} 
jest natomiast, że sam przebieg wojny i jej wynik były uzależnione od zaangażowania zewnętrznego (Moradiellos, 2003, s. 73). Hiszpańska wojna po internacjonalizacji stała się poligonem doświadczalnym dla państw przed decydującym starciem, czyli II wojną światową (zob. Mizerska-Wrotkowska, 2012, s. 161-180).

\section{Bibliografia}

Arbeloa V. M. (2006), La Semana Trágica de la Iglesia en España (8-14 ocetubre de 1931), Ediciones Encuentro, Madrid.

Egido León Á. (2000), La dimensión internacional de la Segunda República: un proyecto en el crisol, w: La politica exterior de España en el siglo XX, red. J. Tusell, J. Avilés, R. Pardo, UNED, Madrid.

Jover Zamora J. M. (1963), Caracteres de la política exterior de España en el siglo XIX, w: Homenaje a Johanes Vincke, vol. II, Consejo Superior de Investigaciones Científicas, Madrid.

Madariaga Álvarez-Prida de M. R. (2009), Salvador de Madariaga y la política exterior española durante la II República, „Revista de Investigaciones Políticas y Sociológicas”, nr 2(8).

Mizerska-Wrotkowska M. (2012), Interwencja zewnętrzna w Hiszpanii podczas wojny domowej (1936-1939), „Społeczeństwo i Polityka” nr 1(30).

Moradiellos E. (2003), La política europea, 1898-1939, w: La política exterior en el siglo XX, red. F. Portero, Ayer-Marcial Pons, Madrid.

Neila Hernández J. L. (2003), El proyecto internacional de la república: democracia, paz y neutralidad (1931-1936), w: La politica exterior de España (1800-2003), red. J. C. Pereira, Ariel, Barcelona.

Olivié F. (1999), La herencia de un Imperio roto, Fundación Cánovas del Castillo, Madrid.

Palomares Lerma D. G. (1994), Pola exterior española: de la dictadura de Primo de Rivera a la guerra civil, w: La política exterior española en el siglo XX, red. R. Calduch, Ediciones de las Ciencias Sociales, Madrid.

Pereira J. C., Neila J. L. (1989), La política exterior durante la II república: un debate y una respuesta, w: Las relaciones internacionales en la España contemporánea, red. J. B. Vilar, Universidad de Murcia, Murcia.

Pereira J. C. (1983), Introducción al estudio de la política exterior de España (siglos XIX y XX), Akal Editor, Madrid.

Powell Ch. T. (1995), Las relaciones exteriores de España, 1898-1975, w: Las relaciones exteriores de la España democrática, red. R. Gillespie, F. Rodrigo, J. Story, Alianza Editorial, Madrid.

Tamames R. (1976), La república. La era de Franco, Alianza Editorial, Madrid.

Tuñón de Lara M. (1997), Druga Republika i hiszpańskie społeczeństwo 1931-1936, w: Historia Hiszpanii, red. M. Tuñón de Lara, J. Valdeón Baruque, A. Domínguez Ortiz, Universitas, Kraków.

\section{The international activity of the Second Spanish Republic}

\section{Summary}

The aim of this article is to show the international activity of Spain between 1931-1936, the period of the Second Republic. The article attempts to answer the following questions: (1) What exactly was the nature of the reorganization of the Spanish diplomatic structures after the change of regime in 1931 ? 
(2) Who was responsible for shaping the foreign policy of Spain during the Second Republic? (3) What were Spain's relations with key actors on the international stage during this period? (4) How did Spanish activity manifest itself in the forum of the League of Nations? The article analyses and criticizes sources of information and makes a comparative analysis of available publications, chiefly in Spanish.

The author concludes that although the Spanish foreign policy during the Second Republic was not impressive, it did reflect the capacity of the state at the time. It was also adapted to the difficult international circumstances and domestic ideological determinants. This policy underwent a transformation - from cultivating the great ideals of pacifism and neutrality to pragmatic neutrality and realism.

Key words: Second Spanish Republic, pacifism, bilateral relations, the League of Nations 
